\section{Benefits of e-CRM Services among Private Banking Customers - A Study with Special Reference to Pollachi Taluk}

\author{
M. Deepa \\ Assistant Professor, PG Department of Commerce (CA) \\ Nallamuthu Gounder Mahalingam College, Pollachi, Tamil Nadu, India \\ https://orcid.org/0000-0002-7683-6299
}

Manuscript ID:

COM-2021-09023823

\begin{abstract}
Banking Industry has witnessed a lot of changes in all the of Liberalization. The advent of foreign banks into the country and the licensing of the private sector have created stiff competition within the business. E-CRM's role is more important for the healthy growth of the banking business and combats the competition from rivals. The objectives of the study are: to identify the benefits enjoyed by the customers while using e-CRM services. The data study is based on the primary data collected by way of a distributed, well-framed questionnaire. There are 120 questionnaires issued among the customers. Convenience sampling methods have been adopted in this study. Some of the findings of the studies are: Most of the consumers are belonging to the age group between 22-30years. Most of the consumers $(66.67 \%)$ are female. The majority of the consumers $(45.00 \%)$ are postgraduates. Most of the Consumers (49.16\%) are married. The majority of the respondents (51.67\%) are residing in the rural area. Some of the suggestions of the study are as follows: To improve user friendly, to secure customer personal information, and Awareness camp must be conducted to educate account holders about e-CRM service, To reduce the service charges and transaction charges. It is concluded that Customer satisfaction was found to be key advantages prove by the bankers while using e-CRM and the main benefit of this e-banking is convenience to the customers. Now a day's consumers mostly prefer to use online banking services because the consumers do not have time to go to the bank and withdraw money, for the consumers need more time.
\end{abstract}

Keywords: Banking, Electronic customer relationship management, Indian Banking

Published: 01.04.2021

Citation:

Deepa, M. "Benefits of e-CRM Services among Private Banking Customers - A Study with Special Reference to Pollachi Taluk." ComFin Research, vol. 9 , no. 2,2021 , pp. 47-49.

DOI:

https://doi.org/10.34293/ commerce.v9i2.3823

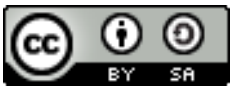

This work is licensed under a Creative Commons Attribution-ShareAlike 4.0 International License

\section{Introduction}

Banking Industry has witnessed a lot of changes in all the of Liberalization. The advent of foreign banks into the country and the licensing of the private sector have created stiff competition within the business. E-CRM's role is more important for the healthy growth of the banking business and combats the competition from rivals. To save time and to concentrate more on marketing and selling, banks to adopt alternate channels like e-banking, m-banking, smart cards, Automated Teller Machines, etc., Electronic Customer Relationship Management (ECRM)has enabled the effectiveness of business transactions in modern economies. E-CRM has pervaded all spheres of human activity.

\section{Techniques of e-CRM used by the Banks}

The following are the e-CRM services are adopted by state banks of India banks.

- Automatic teller machines (ATMs)

- Telex

- Fax

- Internet

- Telebanking / Phone Banking

- Electronic Clearing Services 
- Online banking

- Mobile banking

- Electronic fund transfer (EFT)

- National Electronic Fund Transfer (NEFT)

- Real-Time Gross Settlement (RTGS)

\section{Statement of the Problem}

The concept of the banking sector has undergone significant changes to the services provided is their consumers to find the research gap. The following questions are raised in the mind of the researcher.

- What are the benefits enjoyed by online consumers?

\section{Objective of the Study}

This study is undertaken with the following objectives.

- To identify the benefits enjoyed by the customers while using e-CRM services.

\section{Methodology}

Data: The data study is based on the primary data collected by way of the distributed, well-framed questionnaire.

Sample Size and Sampling Method: There are 120 questionnaires issued among the customers. The convenience sampling method has been adopted in this study.

Tools Used: The following are the important statistical tool used in this present study.

1. Simple percentage and

2. Fried Man Rank test

\section{Summary of Findings}

The findings of this study are divided into two sections, namely personal profile, the benefit of e-CRM services.

- Most of the consumers are belonging to the age group between 22-30 years

- Most of the consumers (66.67\%) are female

- Majority of the consumers $(45.00 \%)$ are post graduates.

- Most of the Consumers (49.16\%) are married

- Majority of the respondents (51.67\%) are residing in rural area

- Majority of the consumers (40.83\%) monthly income above Rs.30,000.
- Most of the consumers $(55.00 \%)$ are nuclear family

- Most of the consumers (85.83\%) are account hold in SBI.

- Most of the consumers 71 (59.16\%) having saving account.

- Most of the consumers are selecting for SBI is their safety usage of SBI bank

- Most of the respondents 83(69.17\%) are using online banking services.

- Most of the consumers (40.83\%) are using ATM card

- Majority of the Consumers (21.67\%) are using Credit Cards for shopping

- Majority of the Consumers (80.00\%) are satisfied with providing SBI bank services

\section{Benefit of e-CRM Services}

The first rank is given to easy transaction, the second rank given to customer loyalty, third rank given to recharge of mobile\& DTH connection, fourth rank given to online bill payment, fifth rank given to online fund transfer, sixth rank given to online shopping Seventh rank given to security, eighth rank given to save time, ninth rank given to accessibility.

\section{Suggestion of the Study}

Some of the suggestions of the study are as follows:

- To improve user friendly

- To secure customer personal information.

- Awareness camp must be conducted to educate account holders about e-CRM service.

- To reduce the service charges and transaction charges.

- The bankers can extend the deposit and withdrawal limit as per the convenience of the consumer.

- The head office may concentrate on branches in semi-urban and rural areas to implement e-CRM solutions.

- Bankers advised the consumers that make fuller utilization of e-CRM services.

- Bankers should ensure the security in the use of internet banking and mobile banking. 


\section{Conclusion}

Customer satisfaction was found to be key advantage prove by the bankers while using e-CRM and the main benefit of this e-banking is convenience to the customers. Now a day's consumers mostly prefer to use online banking services because the consumers do not have time to go to the bank and withdraw money, for the consumers need more time. So, most of the consumer area gives more preference for online banking it easy to do all transaction like fund transfer deposit withdrawal and other services like payment, electronic bills booking air tickets, online share trading.

\section{References}

Agarwal, Aitu. A Comparative Study of Nationalized and Private Banks with Reference to Customer Relationship Management. Punjab University, 2009.

Aher, Ashok Trimbakk. Review of Customer Relationship Management in Banking Sector. Shri Jagadish prasad Jhabarmal Tibrewala University, 2012.

Al-Dmour, Hani H., et al. "Investigating the Impact of ECRM Success Factors on Business Performance: Jordanian Commercial Banks." Asia Pacific Journal of Marketing and Logistics, vol. 31, no. 1, 2019, pp. 105-127.

Ashok Kumar, J. "Customer Relationship Management Practices in Banking Sector in Virudhunagar District." Shanlax International Journal of Commerce, vol. 5, no. 1, 2017, pp. 1-8.
Buttle, Francis. Customer Relationship Management: Concepts and Tools. Elsevier, 2004.

Kotler, Philip. Marketing Management: Analysis, Planning, Implementation and Control. Prentice Hall, 1998.

Kumar, A., et al. "A Study of E-CRM Services of Commercial Banks in Madurai." Shanlax International Journal of Commerce, vol. 7, no. 1, 2019, pp. 39-44.

Lovelock, Christopher H. Services Marketing: People, Technology, Strategy. Pearson Education, 2001.

Peppers, Don, and Martha Rogers. Managing Customer Relationships: A Strategic Framework. John Wiley \& Sons, 2004.

Sathiya, N. A Study on Customer Relationship Management Practices in Banking Sector. Periyar University, 2011.

Sheth, Jagdish N., et al. Customer Relationship Management: Emerging Concepts, Tools and Applications. Tata McGraw-Hill Publishing Company Limited, 2001.

Vijayakumar, T. A Study on Customer Relationship Management in Retail Banks with Reference to Kanchipuram District, Tamilnadu. SRM University, 2011.

Yadav, Anil Kumar. A Study of Customer Relationship Management (CRM) Practices in Banking Sector. Shri Jagadish Prasad Jhabarmal Tibrewala University, 2013.

Zikmund, William G. Customer Relationship Management: Integrating Marketing Strategy and Information Technology. Wiley, 2002.

\section{Author Details}

Dr. M. Deepa, Assistant Professor, PG Department of Commerce (CA), Nallamuthu Gounder Mahalingam College, Pollachi, Tamil Nadu, India, Email ID: deepakathirvel18@gmail.com 